\title{
Exploring the Influence of Belgian and South-African Corporate Governance Codes on IT Governance Transparency
}

\author{
Tim Huygh \\ University of Antwerp, \\ Antwerp, Belgium \\ Tim.huygh@uantwerpen.be \\ Wim Van Grembergen \\ University of Antwerp, \\ Antwerp, Belgium \\ Wim.vangrembergen@uantwerpen.be
}

\author{
Steven De Haes \\ University of Antwerp, \\ Antwerp, Belgium \\ Steven.dehaes@uantwerpen.be \\ Denis Gui \\ University of Antwerp, \\ Antwerp, Belgium \\ Denis.gui@student.uantwerpen.be
}

\author{
Anant Joshi \\ Maastricht University, \\ Maastricht, The Netherlands \\ A.joshi@maastrichtuniversity.nl
}

\begin{abstract}
Building on prior research on how boards should provide stakeholder transparency by disclosing on how their organizations are governing their IT assets, this paper provides an exploratory insight in the contemporary state of IT governance transparency in Belgian and South African companies. Specifically, the influence of the national corporate governance code on IT governance transparency is investigated by comparing both groups of companies. Our findings show that South African firms tend to be more concerned with IT governance transparency than Belgian firms, given a comparable IT strategic role and ownership structure. This result could be expected, as the South African corporate governance code, King III, contains specific IT (governance)-related guidance, while the Belgian code Lippens does not. Accordingly, the case is made for including more (non-committal) IT (governance)-related guidance in national corporate governance codes.
\end{abstract}

\section{Introduction}

The potential benefits of IT governance are known for over a decade now. Weill \& Ross [1] state that "effective IT governance is the single most important predictor of the value an organization generates from $I T$ ". Many studies have surfaced that identified mechanisms for IT governance (e.g. [1]-[4]). Due to a direct link between corporate governance and IT governance [1], many corporate governance mechanisms are translated into the IT governance domain. An important issue in corporate governance literature is transparency, or disclosure [5]-[7]. However, the issue of IT governance transparency/disclosure, which is about providing stakeholders with information about the way the organization is governing its IT assets, has received little attention in academic research [8]. Joshi et al. [8] proposed a framework to assess the level of IT governance disclosure, together with a call for additional empirical research to contribute to the under-researched topic of IT governance disclosure. In response we aim to make an exploratory empirical contribution to the field of IT governance transparency. The main objective of this study is to investigate the influence of the national corporate governance code on a firm's IT governance transparency. Indeed, there could be potential variations in IT governance disclosure due to variations in the national corporate governance code. This objective is approached by comparing the IT governance disclosure of two groups of firms: i.e. Belgian and South African firms. Differences in IT governance transparency between these two groups of companies can be expected, as the South African corporate governance code, King III, contains a significant amount of IT (governance)related guidance, while the Belgian code Lippens does not. While controlling for the IT strategic role and firm ownership structure, the investigation of the effect of the national corporate governance code on a firm's tendency to disclose on its IT governance is an important contribution to extant literature.

Following the problem statement and research objective discussed in the previous paragraph, the following research question is put forward: "To what extent does the national corporate governance code influence the level of IT governance disclosure of a firm?"

From this research question, the following proposition is derived: Firms that are submitting their annual report based on a corporate governance code that 
contains (non-committal) IT (governance)-related guidance disclose more on their IT governance compared to firms that are submitting their annual report based on a corporate governance code that contains no IT (governance)-related guidance. This proposition has important consequences for the sampling criteria, which will be discussed in the 'research approach' section. It should be noted that this proposition serves a more directive purpose, rather than conclusive, as the small sample size $(\mathrm{N}=20)$ used in this research does not allow for formal statistical significance testing. Nevertheless, we aim to provide an in-depth qualitative discussion of the issues at hand.

The remainder of this paper is structured as follows. The second section provides a theoretical background to this research by discussing the concepts of IT governance and IT governance transparency, followed by a short discussion of the IT governance transparency framework by Joshi et al. [8], which will be used during our exploratory empirical research by serving as the measurement instrument of the IT governance disclosure construct. The third section presents the research scope and the research approach. The fourth section presents the results and conclusions of the empirical research. The fifth section presents the research implications (for theory and practice). Finally, the sixth section presents the limitations of this research, accompanied by translations into opportunities for future research.

\section{Theoretical background}

\subsection{IT governance}

IT governance is an integral part of corporate governance [9], considering IT governance exists in the realm of overall corporate governance [1]. De Haes \& Van Grembergen [9, p. 2] define the concept as "an integral part of corporate governance and addresses the definition and implementation of processes, structures and relational mechanisms in the organization that enable both business and IT people to execute their responsibilities in support of business/IT alignment and the creation of business value from IT-enabled business investments". Over time, IT governance gained momentum due to more companies becoming critically dependent on IT for their strategic and operational business activities [9], [10].

The above-mentioned definition by De Haes \& Van Grembergen (op. cit.) clearly indicates that IT governance is an integral part of corporate governance, requiring involvement of the board. Due to this direct link between both concepts, many of the issues that are discussed regarding corporate governance also apply to IT governance [11]-[13]. Drawing on the ideas of corporate governance, IT governance can be implemented using structures, processes, and relational/communication mechanisms [3], [14]. In the IT governance body of knowledge, many different mechanisms are reported, such as strategy committees, steering committees, a portfolio management process, etc. [1]-[4]. An important issue in corporate governance literature is transparency [5]-[7]. However, the issue of IT governance transparency has received little attention to this date in academic research [8].

\subsection{IT governance transparency}

The disclosure of non-financial information improves the value of a firm's stock due to a reduction of information asymmetry [15]. Therefore, such disclosure is essential for organizations that are seeking for investors. As IT (governance)-related information is a subset of non-financial information, IT governance disclosure should also be considered by organizations as a means to improve firm value. The importance of transparency about IT governance is mentioned in literature [13], but is to this date vastly underresearched compared to disclosure about overall corporate governance [8]. IT governance transparency can be defined as "the ability of firms to provide adequate and relevant IT governance information in a timely and effective manner to their stakeholders, such as investors, policy makers, and regulatory bodies, so that they can assess management's behavior in using $I T$ ” [8, p. 118]. It should be noted that IT governance transparency can be about internal transparency (e.g. by making IT governance practices known on the firm's intranet), as well as external transparency. It is important to stress that this research deals with public voluntarily disclosure about IT governance (i.e. with the goal of informing external stakeholders). The international good-practice framework for enterprise governance and management of IT, COBIT 5, also refers to the importance of ensuring stakeholder transparency in the context of IT governance. In its process reference model, COBIT 5 describes this process, EDM05 'Ensure stakeholder transparency', as required to "ensure that enterprise IT performance and conformance measurement and reporting are transparent, with stakeholders approving the goals and metrics and the necessary remedial actions" [16, p. 47].

Joshi et al. [8] present an IT governance disclosure framework based on the IT governance focus areas as 
defined by the IT Governance Institute (ITGI) [17]. Specifically, their IT governance disclosure framework contains 39 disclosure items and is built around the following domains: IT strategic alignment, IT value delivery, IT risk management, and IT performance measurement. 'IT strategic alignment' deals with the fact that IT investments need to support the strategic goals and objectives of an organization in order to enable the creation of current and future business value. 'IT value delivery' is concerned with the optimization of IT-enabled value creation, where value is broader than strictly monetary (e.g. competitive advantage, higher employee productivity, etc.). 'IT risk management' is concerned with the protection of ITassets and recovery from IT-related disasters. Finally, 'IT performance measurement' is related to the IT budget and IT investments. It is specifically concerned with the expenditure on IT resources and its association to business value. For this research, the IT governance disclosure framework will serve as operationalization of the IT governance disclosure construct.

The conceptual model for this research is presented in Figure 1. This representation is based on Libby's predictive validity framework [18], which emphasizes the important role of careful conceptual specification of constructs in theory-based empirical research. The dashed boxes represent the conceptual level, while the boxes below represent the operationalization of the concepts used in this research. The concept of IT governance transparency will be operationalized using the IT governance disclosure rate derived from the IT governance transparency framework by Joshi et al. [8]. The concept of corporate governance code will be operationalized by means of Boolean categorization: either the code contains (non-committal) IT (governance)-related guidance or it does not. This is to enable the comparison of IT governance disclosure between two groups of interest, in line with our proposition.

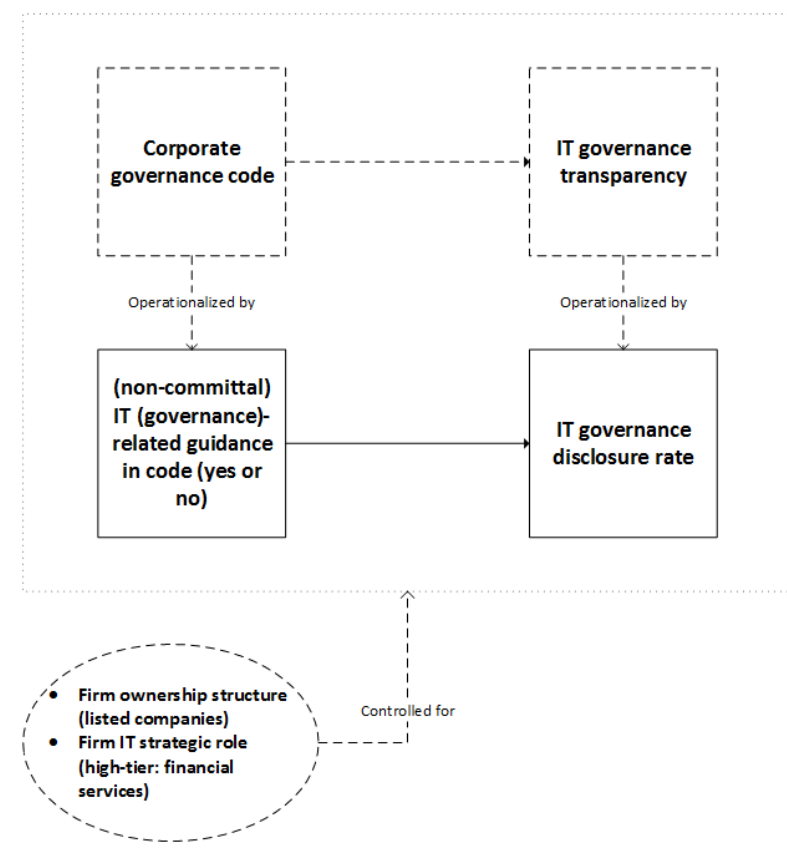

Figure 1. Conceptual model and operationalization

\section{Research methodology}

\subsection{Research scope}

This study focuses on public corporate disclosure of IT governance (i.e. with the goal of informing external stakeholders). To improve the internal validity of this research project, the research was scoped down in order to control for potential contingency factors. Specifically, this research project was scoped down to financial services organizations to control for IT strategic role, and to listed companies to control for ownership structure. For controlling IT strategic role, we follow Sohal \& Fitzpatrick [19], who discern between "high tier industries" and "low tier industries". High tier industries are characterized by the fact that IT is the most important factor to influence the core business of a company. Examples of such industries are banking, communications, and insurance. On the other hand, in low tier industries IT is generally used at an operational level only, to provide automated support of basic tasks. Examples of such industries are transportation, construction, manufacturing, and natural resources. Because of differences in IT strategic role between industries, there might also be differences in IT governance maturity [9], which could obscure the effect of the national corporate governance code (if any) on IT governance transparency. For controlling ownership structure, it was decided to only select listed companies, as the disclosure of nonfinancial information improves the value of a firm's stock, due to a reduction of information asymmetry 
[15]. Hence, firms that are publicly listed can be expected to disclose more on their IT governance, as part of non-financial disclosure in general, compared to firms that are not publicly listed, as they have more incentive to do so. The focus on listed companies might therefore yield more interesting results.

The corporate governance code of South Africa, King III, is a rather unique code as it contains directives on IT governance [20]. King III came into effect for South African entities starting from 1 March 2010 and is applicable to all entities (i.e. regardless of their size and whether or not they are listed). Specifically, King III contains seven IT governance principles (Table 1) and some additional more detailed recommended practices for each of these principles. Belgium has two corporate governance codes: the code Lippens for listed companies (often referred to as 'code 2009'), and the code Buysse for non-listed companies. Both of these codes have in common, together with many corporate governance codes around the world, that they do not contain any specific IT (governance)-related guidance. To be technically correct, the code Lippens is applicable for this research, as we control for listed companies. King III and code Lippens both start from the "comply-or-explain" principle, ultimately meaning that the guidance contained in the codes is noncommittal.

In summary, only listed financial services organizations from Belgium and South Africa will be sampled. This is done to improve the internal validity of this exploratory research, as well as to enable the comparison of two groups as stated in the proposition.

Table 1. King III IT governance principles

\begin{tabular}{|l|l|}
\hline Principle & \multicolumn{1}{c|}{ Description } \\
\hline 5.1 & $\begin{array}{l}\text { The board should be responsible for } \\
\text { information technology governance. }\end{array}$ \\
\hline 5.2 & $\begin{array}{l}\text { IT should be aligned with the performance } \\
\text { and sustainability objectives of the entity. }\end{array}$ \\
\hline 5.3 & $\begin{array}{l}\text { The board should delegate the } \\
\text { responsibility for the implementation of an } \\
\text { IT governance framework to management. }\end{array}$ \\
\hline 5.4 & $\begin{array}{l}\text { The board should monitor and evaluate } \\
\text { significant IT investments and } \\
\text { expenditure. }\end{array}$ \\
\hline 5.5 & $\begin{array}{l}\text { IT should form an integral part of the } \\
\text { entity's risk management process. }\end{array}$ \\
\hline 5.6 & $\begin{array}{l}\text { The board should ensure that information } \\
\text { assets are managed effectively. }\end{array}$ \\
\hline 5.7 & $\begin{array}{l}\text { A risk committee and audit committee } \\
\text { should assist the board in carrying out its } \\
\text { IT responsibilities. }\end{array}$ \\
\hline
\end{tabular}

\subsection{Research approach}

The research started with a literature review to anchor the study and to define the main concepts used in the research project. For the empirical research stage, the following approach was used. First, the research deals with a purposive sample of firms conform the scope. Specifically, two groups of ten firms are selected. This smaller sample size is due to our specific focus to improve the internal validity of the research. The first group consists of Belgian financial services firms that are listed on Euronext Brussels, while the second group consists of South African financial services firms that are listed on the Johannesburg Securities Exchange (JSE). The selection of these groups is in line with the specified research question and proposition. It should be noted that the goal of this paper is not to provide a high level of generalizability of the results. Rather, we focus on the internal validity of the research, while providing an in-depth view on the issues that are investigated. The final sample is presented in Table 2.

Table 2. Firms in the sample $(\mathrm{N}=20)$

\begin{tabular}{|l|l|}
\hline \multicolumn{1}{|c|}{ Belgian group } & \multicolumn{1}{|c|}{ South African group } \\
\hline Ageas & ABSA Bank Limited \\
\hline Ascencio & $\begin{array}{l}\text { Alexander Forbes Group } \\
\text { Holdings }\end{array}$ \\
\hline Befimmo & Clientele Limited \\
\hline Dexia & $\begin{array}{l}\text { Discovery Holdings } \\
\text { Limited }\end{array}$ \\
\hline GBL & Grindrod Bank \\
\hline Iep Invest & $\begin{array}{l}\text { Liberty Holdings } \\
\text { Limited }\end{array}$ \\
\hline KBC & MMI Holdings Limited \\
\hline $\begin{array}{l}\text { Nationale Bank van } \\
\text { België }\end{array}$ & Sanlam \\
\hline Sofina & Santam \\
\hline Solvac & Sasfin Bank \\
\hline
\end{tabular}

For each firm in the sample the English annual report of 2014 was obtained and analyzed, as these were the most recent available at the time. The annual report is a public disclosure document that is available for all firms. Additionally, Joshi et al. [8] found that the annual report seems to be the preferred medium for sharing information regarding IT governance. The analysis of the annual reports of 2014 for all firms implies a cross-sectional analysis. The qualitative data analysis procedure that was used is conceptual content analysis, also known as thematic analysis. This enables the analysis of the existence and frequencies of concepts of interest based on a coding frame [21], and is therefore very suitable for our purpose. Applied to this research, IT governance disclosure items will be 
identified in the annual reports, using the IT governance disclosure framework [8] as a coding frame. Each annual report is manually analyzed, applying dichotomous coding for each disclosure item in the framework (i.e. a score of ' 1 ' if the item is present in the annual report and a score of ' 0 ' otherwise). Joshi et al. [8] provide a definition for each disclosure item that was included in the disclosure framework, hence improving the content or face validity of the items and as such supporting the objectivity of the coding process. For each category of the IT governance disclosure framework, an 'IT governance disclosure rate' can be calculated as $\frac{1}{n} \sum_{i=1}^{n} x_{i}$

\section{Results}

In order to provide an answer to the research question (and the proposition that was derived from this research question), an analysis was performed between financial services organizations that are listed on Euronext Brussels (and therefore subject to the Belgian code Lippens), and financial services organizations that are listed on the Johannesburg securities exchange (and therefore subject to the South African code King III). The results of this analysis are first overviewed at the level of the disclosure categories in Table 3. The group with the highest average disclosure rate for each disclosure category is bold-faced.

Table 3. Reporting rate per disclosure category

\begin{tabular}{|l|l|l|l|}
\multicolumn{1}{c|}{} & \multicolumn{1}{c}{$\begin{array}{c}\text { Belgian } \\
\text { companies } \\
(\mathbf{N}=\mathbf{1 0})\end{array}$} & $\begin{array}{c}\text { South } \\
\text { African } \\
\text { companies } \\
(\mathbf{N = 1 0 )}\end{array}$ & $\begin{array}{c}\text { Full } \\
\text { sample } \\
(\mathbf{N}=\mathbf{2 0})\end{array}$ \\
\hline $\begin{array}{l}\text { IT strategic } \\
\text { alignment }\end{array}$ & $8 \%$ & $\mathbf{2 5 \%}$ & $16.5 \%$ \\
\hline $\begin{array}{l}\text { IT value } \\
\text { delivery }\end{array}$ & $6 \%$ & $\mathbf{3 8 \%}$ & $22 \%$ \\
\hline $\begin{array}{l}\text { IT risk } \\
\text { management }\end{array}$ & $21 \%$ & $\mathbf{3 3 \%}$ & $27 \%$ \\
\hline $\begin{array}{l}\text { IT } \\
\text { performance } \\
\text { measurement }\end{array}$ & $16 \%$ & $\mathbf{2 9 \%}$ & $22.5 \%$ \\
\hline Average & $\mathbf{1 2 . 7 5 \%}$ & $\mathbf{3 1 . 2 5 \%}$ & $\mathbf{2 2 \%}$ \\
\hline
\end{tabular}

This first global overview of IT governance transparency between both groups shows that the listed South African financial services organizations seem to be more concerned with disclosing on their IT governance than the listed Belgian financial services organizations. This observation holds for all disclosure categories of the IT governance transparency framework. This result could be expected, as King III contains (non-committal) IT (governance)-related guidance while the code Lippens does not. We conclude that our empirical research points at some evidence for the justification of the proposition. Table 3 also globally indicates that there are potential opportunities for the firms in our sample to improve on their IT governance transparency. While this is true for both groups, it is especially true for the Belgian firms.

Next, we investigate the IT governance disclosure at item-level, which enables some deeper discussion. These results are displayed in Table 4.

Table 4. Item-level reporting rates

\begin{tabular}{|l|l|l|}
\hline \multicolumn{1}{|c|}{ IT strategic alignment items } & \multicolumn{1}{|c|}{$\begin{array}{c}\text { BE } \\
(\mathbf{N}=10)\end{array}$} & \multicolumn{1}{|c|}{$\begin{array}{c}\text { SA } \\
(\mathbf{N}=10)\end{array}$} \\
\hline IT expert on the board & $1 / 10$ & $\mathbf{2 / 1 0}$ \\
\hline $\begin{array}{l}\text { IT expert with experience on the } \\
\text { board }\end{array}$ & 0 & $\mathbf{2 / 1 0}$ \\
\hline $\begin{array}{l}\text { A CIO or an equivalent position } \\
\text { in the firm }\end{array}$ & $3 / 10$ & $\mathbf{5 / 1 0}$ \\
\hline IT committee & 0 & $\mathbf{3 / 1 0}$ \\
\hline $\begin{array}{l}\text { IT risk is part of audit committee } \\
\text { or risk committee }\end{array}$ & $3 / 10$ & $\mathbf{6 / 1 0}$ \\
\hline IT is part of audit committee & $1 / 10$ & $\mathbf{4 / 1 0}$ \\
\hline IT steering committee & 0 & $\mathbf{3 / 1 0}$ \\
\hline IT planning committee & $\mathbf{0}$ & $\mathbf{0}$ \\
\hline Technology committee & 0 & $\mathbf{1 / 1 0}$ \\
\hline $\begin{array}{l}\text { IT committee at an executive } \\
\text { level }\end{array}$ & $\mathbf{1 / 1 0}$ & $\mathbf{1 / 1 0}$ \\
\hline CIO or equivalent is on the board & 0 & $\mathbf{1 / 1 0}$ \\
\hline Reporting rate (average) & $\mathbf{8 \%}$ & $\mathbf{2 5 \%}$ \\
\hline \multicolumn{1}{|c|}{ IT value delivery items } & $\mathbf{B E}$ & $\mathbf{S A}$ \\
\hline $\begin{array}{l}\text { IT governance } \\
\text { framework/standard: } \\
\text { ITIL/COBIT/ISO etc. }\end{array}$ & 0 & $\mathbf{9 / 1 0}$ \\
\hline $\begin{array}{l}\text { IT as an issue in the board } \\
\text { meeting }\end{array}$ & 0 & $\mathbf{6 / 1 0}$ \\
\hline $\begin{array}{l}\text { Suggestion/decision/advise by the } \\
\text { board on IT }\end{array}$ & 0 & $\mathbf{1 / 1 0}$ \\
\hline $\begin{array}{l}\text { Special report/section on IT/IT } \\
\text { projects in annual report }\end{array}$ & $1 / 10$ & $\mathbf{8 / 1 0}$ \\
\hline $\begin{array}{l}\text { IT mentioned as a strategic } \\
\text { business issue }\end{array}$ & $3 / 10$ & $\mathbf{7 / 1 0}$ \\
\hline IT projected as strength & 0 & $\mathbf{3 / 1 0}$ \\
\hline IT projected as opportunity & 0 & $\mathbf{2 / 1 0}$ \\
\hline Project updates or comments & $2 / 10$ & $\mathbf{3 / 1 0}$ \\
\hline $\begin{array}{l}\text { IT is explicitly mentioned for } \\
\text { achieving specific business } \\
\text { objectives }\end{array}$ & $1 / 10$ & $\mathbf{3 / 1 0}$ \\
\hline $\begin{array}{l}\text { Comments/updates on IT } \\
\text { performance }\end{array}$ & 0 & $\mathbf{4 / 1 0}$ \\
\hline IT training & $\mathbf{2 / 1 0}$ \\
\hline
\end{tabular}




\begin{tabular}{|c|c|c|}
\hline Green IT & $\mathbf{0}$ & $\mathbf{0}$ \\
\hline $\begin{array}{l}\text { Direction and status about IT } \\
\text { outsourcing and in-sourcing }\end{array}$ & 0 & $\mathbf{1} / \mathbf{1 0}$ \\
\hline Reporting rate (average) & $6 \%$ & $38 \%$ \\
\hline IT risk management items & $\begin{array}{c}\mathrm{BE} \\
(\mathrm{N}=10)\end{array}$ & $\begin{array}{c}\text { SA } \\
(\mathbf{N}=10)\end{array}$ \\
\hline $\begin{array}{l}\text { IT is referred under the } \\
\text { operational risk }\end{array}$ & $6 / 10$ & $5 / 10$ \\
\hline $\begin{array}{l}\text { Special IT risk management } \\
\text { program }\end{array}$ & $3 / 10$ & $2 / 10$ \\
\hline $\begin{array}{l}\text { Use of IT for regulation and } \\
\text { compliance }\end{array}$ & 0 & $5 / 10$ \\
\hline $\begin{array}{l}\text { IT/electronic data processing } \\
\text { (EDP) audit }\end{array}$ & 0 & $2 / 10$ \\
\hline $\begin{array}{l}\text { Information and security } \\
\text { policy/plan (IT security) }\end{array}$ & $2 / 10$ & $5 / 10$ \\
\hline $\begin{array}{l}\text { The role of IT in accounting and } \\
\text { the reporting standards (IAS) }\end{array}$ & $2 / 10$ & $2 / 10$ \\
\hline Operations continuity plan & $2 / 10$ & $2 / 10$ \\
\hline Reporting rate (average) & $21 \%$ & $33 \%$ \\
\hline $\begin{array}{l}\text { IT performance measurement } \\
\text { items }\end{array}$ & $\begin{array}{c}\mathrm{BE} \\
(\mathrm{N}=10)\end{array}$ & $\begin{array}{c}\mathrm{SA} \\
(\mathbf{N}=\mathbf{1 0})\end{array}$ \\
\hline $\begin{array}{l}\text { Explicit information on IT } \\
\text { expenditure }\end{array}$ & 0 & $4 / 10$ \\
\hline IT budget & $\mathbf{0}$ & $\mathbf{0}$ \\
\hline IT hardware cost & $4 / 10$ & $4 / 10$ \\
\hline IT software cost & $6 / 10$ & $7 / 10$ \\
\hline $\begin{array}{l}\text { Explicit IT manpower cost is } \\
\text { mentioned }\end{array}$ & $\mathbf{0}$ & $\mathbf{0}$ \\
\hline $\begin{array}{l}\text { IT expenses are mentioned under } \\
\text { administrative cost }\end{array}$ & 0 & $\mathbf{1} / \mathbf{1 0}$ \\
\hline $\begin{array}{l}\text { IT related assets are mentioned } \\
\text { under intangible assets }\end{array}$ & $3 / 10$ & $7 / 10$ \\
\hline $\begin{array}{l}\text { Direct cost on IT is mentioned in } \\
\text { currency or percentage }\end{array}$ & $\mathbf{0}$ & $\mathbf{0}$ \\
\hline Reporting rate (average) & $16 \%$ & $29 \%$ \\
\hline
\end{tabular}

The group with the highest disclosure rate for each item is bold-faced (both groups in the case of a draw). In line with the previous discussion about the results per disclosure category, the South African companies show higher reporting rates on almost all of the individual items.

\subsection{IT strategic alignment}

With an average of $16.5 \%$ over the whole sample $(\mathrm{N}=20)$, 'strategic alignment' is the least reported upon among the four disclosure categories of the IT governance transparency framework. This is a surprising result, since IT governance is the responsibility of the board [9] and the majority of the items in the IT strategic alignment category are specifically situated at the board level (e.g. 'IT expert on the board', 'IT expert with experience on the board', 'CIO or equivalent is on the board', 'IT committee' etc.). Academic literature indicates that a high degree of board involvement in IT governance, and IT experience at the board, has a positive effect on organizational performance [10], [22], [23]. Despite acknowledging the importance of board involvement in IT governance, Nolan \& McFarlan [10] state that boards are often not aware of the importance of IT when it comes to supporting corporate objectives and the need for alignment between the overall corporate strategy and the IT strategy. Additionally, the board is often incapable to ask IT management "the right questions" due to a lack of expertise, leading to the inability to effectively monitor the management of IT [23]. Strategic alignment is also often perceived as a very complex challenge, to the point where decision makers are unsure about how to approach the alignment challenge [24]. It should also be noted that putting the $\mathrm{CIO}$ (or equivalent) on the board, putting an IT expert at the board, or putting an IT committee in place at the level of the board, can help in solving these issues [3]. This seems to be an opportunity for the organizations in the sample, as for instance only one South African firm explicitly reports having a CIO or equivalent on the board, and only three South African firms report on having a board-level IT committee. None of the Belgian firms report on these two items. The previous discussion is entirely in line with principle 5.1 of King III, i.e. "the board should be responsible for IT governance", clearly pointing at the need for board involvement in IT governance. The issue of strategic alignment is articulated in principle 5.2 of King III, i.e. "IT should be aligned with the performance and sustainability objectives of the company".

When the CIO (or equivalent) is not on the board, the firm can still have such a position. Practice 5.3.3 of King III states that "the CEO should appoint a CIO responsible for the management of IT". Remarkably, only half of the firms in the South African sample report on the existence of a CIO position (or equivalent) at the firm. The importance of a CIO position has also been the subject of academic research. Chatterjee, Richardson, \& Zmud [25] found that investors tend to reward the announcement of a new CIO position in organizations that are operating in an industry that is subject to IT-enabled transformation (like financial services). The CIO appointment enables confidence in the capability of the firm to effectively manage its IT assets. While it is not explicitly articulated in King III that the CIO should be on the board, King III's recommended practice 5.3.4 states that "the CIO should be a suitably qualified and experienced person who should have access and 
interact regularly on strategic IT matters with the board and/or appropriate board committee and executive management".

Strategic alignment items 'IT risk is part of audit committee or risk committee' and 'IT is part of audit committee' can be linked to King III's principle 5.7 'A risk committee and audit committee should assist the board in carrying out its IT responsibilities'. This might explain why these items are reported upon more frequently by the South African firms in the sample. Strategic alignment item 'IT steering committee' is addressed in recommended practice 5.3.2 of King III: "The board may appoint an IT steering committee or similar function to assist with its governance of IT". Only 3 out of 10 South African firms report on having such an IT steering committee (as opposed to 0 Belgian firms), which might be due to the careful formulation of this recommended practice (i.e. 'may' instead of 'should').

\subsection{IT value delivery}

For the IT value delivery category, the difference of the average reporting rate between Belgian and South African firms is largest. For the Belgian firms, it is the category which is with $6 \%$ least reported upon, while for the South African firms it is the category which is with $38 \%$ most frequently reported upon. When it comes to IT value delivery in general, King III's recommended practice 5.4.1 explicitly states that "the board should oversee the value delivery of IT and monitor the return on investment from significant IT projects". Academic research has already identified the importance of disclosing about IT investments. Investors tend to reward disclosure about IT investments when they expect that these investments will have a positive effect on current and future business value [26], [27].

There are a few items in the IT value delivery category that are very dominant in establishing the large difference in average disclosure rate between the Belgian and South African firms. First, 'IT governance framework/standard' is reported upon by 9 out of 10 South African firms as opposed to 0 Belgian firms. This can potentially be attributed to King III's principle 5.3, which specifically mentions that an IT governance framework should be implemented by management. Second, 'IT as an issue in the board meetings' is reported upon by 6 out of 10 South African firms as opposed to 0 Belgian firms. Once more, this can be linked to King III's principle 5.1 in general, and recommended practice 5.1.1 in specific: "The board should assume the responsibility for the governance of IT and place it on the board agenda". Third, the item 'special report/section on IT/IT projects in annual report' was found in 8 out of 10 South African firms as opposed to 1 out of 10 Belgian firms. As King III contains a chapter dedicated to IT governance, addressing several principles and recommended practices, it makes sense for firms to cluster these issues in their annual reports. As previously stated, the Belgian code Lippens does not contain any IT governance principles or practices. It is also our belief that including a specific section on ITrelated matters in the annual report enables firms to think about ways to disclose on their IT governance and IT management arrangements, thereby increasing their overall IT governance transparency. Indeed, South African firms appear to be guided in this direction because of the contents of King III.

\subsection{IT risk management}

The IT risk management category is with $21 \%$ the most frequently reported upon category for the Belgian firms in the sample, while still trailing behind the South African firms in average disclosure rate. For the South African firms, IT risk management is with $33 \%$ the second most reported upon of the four disclosure categories. King III also contains specific principles and recommended practices in the area of IT risk management and IT security. Principle 5.5 is 'IT should form an integral part of the company's risk management'. Additionally, King III's recommended practice 5.7.2 states that "The risk committee should obtain appropriate assurance that controls are in place and effective in addressing IT risks". It is therefore somewhat surprising that IT risk management item 'special IT risk management program' is only mentioned in 2 out of 10 annual reports of South African financial services organizations. South African firms report considerably more on 'use of IT for regulation and compliance', which is somewhat related to King III's recommended practice 5.5.2: "the board should ensure that the company complies with IT laws and that IT related rules, codes and standards are considered". South African firms also appear to be more concerned with reporting on IT security compared to Belgian firms. King III's recommended practices belonging to principle 5.6 are especially related to this disclosure item: 5.6.1 "the board should ensure that there are systems in place for the management of information which should include information security, information management and information privacy"; 5.6.2 "the board should ensure that all personal information is treated by the company as an important business asset and is identified"; 5.6.3 "the board should ensure that an information security 
management system is developed and implemented"; and 5.6.4 "the board should approve the information security strategy and delegate and empower management to implement the strategy". Despite all of these IT security-related recommended practices in King III, we find only half of the South African firms in the sample to be reporting on this IT security item. This is especially noteworthy as we are dealing strictly with financial services organizations, a sector which is known to be dealing with large amounts of confidential data, making IT security a necessity. Academic research also indicates the need for IT security. For instance, Campbell, Gordon, Loeb, \& Zhou [28] found that a security breach, leading to unauthorized access to confidential data has a significant negative impact on the value of a firm's stock. Gordon, Loeb, \& Sohail [29] found a positive correlation between the voluntarily disclosure about information security and the market value of a company.

\subsection{IT performance measurement}

The IT performance measurement category shows no significant differences in reporting rates between Belgian and South African firms. There are three dominant categories in this group: 'IT software cost'; 'IT related assets are mentioned under intangible assets'; and 'IT hardware cost'. This appears to be true for the Belgian firms as well as the South African firms. King III does not contain any directives in its principles and recommended practices relating to IT performance measurement. Nevertheless, a possible explanation for the dominance of these items can be found in financial reporting regulation. Listed companies need to report their consolidated annual reports following the International Accounting Standards (IAS). IAS 38 puts software under intangible assets. Unsurprisingly, most Belgian and South African firms in our sample specifically mention software cost and place it under intangible assets in their financial statements. Belgian and South African firms tend to report on hardware cost as well in their financial statements, which falls under IAS 16 regulation.

'Explicit information on IT expenditure' is more reported by South African firms than Belgian firms. The former firms disclose this specific item in 4 out of 10 cases, while this is true for none of the Belgian firms. This might be seen in the overall realm of more IT governance transparency for the South African firms: when most annual reports contain a specific section with attention for IT-related matters, it also makes sense to provide more detail on IT-related expenses in the financial statements. This is therefore a clear opportunity for the Belgian firms in the sample to be more transparent about. In the practitioner area, IT managers report that IT expenditure is a critical attention point for them. According to ITGI [30] survey results, $45.3 \%$ of the respondents were planning initiatives to reduce IT expenditure. Also, $38.7 \%$ of the respondents indicated that the increasing IT expenditure was perceived as a problem. Considering this, it is strange that none of the annual reports contains information about the IT budget, as this is clearly a related issue. The estimation of IT-related costs is notoriously difficult [31]. As firms have difficulties in estimating the IT budget, they might also be reluctant to reporting these figures in their annual reports. Another plausible reason for the absence of IT budget in the annual reports might be that firms are attempting to reduce proprietary costs.

\subsection{Conclusions}

This paper provided an exploratory insight in the contemporary state of IT governance transparency in Belgian and South African firms. We started from the premise that the issue of IT governance transparency has received little attention in academic research. The main objective of this paper was to explore the influence of the national corporate governance code on IT governance transparency. This objective was approached by comparing the IT governance disclosure, using an established IT governance transparency framework from literature, of two groups of firms (i.e. Belgian and South African firms). These groups were purposively chosen, as the South African corporate governance code King III contains specific IT governance guidance, while the Belgian code Lippens does not. While controlling for the IT strategic role by focusing on financial services organizations only, and firm ownership structure by focusing only on listed companies; the investigation of the effect of the national corporate governance code on a firm's tendency to disclose on its IT governance was explored.

The main conclusion of this exploratory research is that the listed South African financial services organizations seem to be more concerned with disclosing on their IT governance than the listed Belgian financial services organizations. This observation holds for all disclosure categories of the IT governance transparency framework. Nevertheless, there are still potential opportunities for the firms in our sample to improve on their IT governance transparency. While this is true for both groups, it is especially true for the Belgian firms, as this group is trailing behind the South African group for all categories of the disclosure framework. Subsequent 
analysis at the item-level also indicates that many of the items on which South African firms tend to report frequently can be directly related to the IT governance principles and recommended practices contained in the King III corporate governance code. We therefore conclude that the higher IT governance transparency of the South African firms might very well be attributed to the contents of their national corporate governance code.

\section{Implications (for theory and practice)}

From an academic point of view, this research adds to the relatively unexplored domain of IT governance transparency. Specifically, this research adds to the empirical backbone of IT governance transparency as a research subject in general, and the IT governance disclosure framework in specific. This research extends prior empirical research regarding IT governance disclosure by investigating the influence of the national corporate governance code on IT governance transparency. Using the Joshi et al. [8] IT governance disclosure framework, we were able to collect some preliminary empirical evidence in support of the indicated proposition.

From a practitioners' stance, we believe that this exploratory research illustrates the need for including IT governance-related directives in national corporate governance codes. As IT becomes more pervasive in firms all over the world, it makes sense for firms to be transparent about these, often very important, ITrelated matters; and for national corporate governance codes to guide firms in such a direction. This study also help to explore the fundamental role of corporate governance principles in shaping IT governance practices at firm level by providing evidence that the presence of IT-related principles in corporate governance codes can encourage firms in disseminating IT governance information in public documents. The importance of IT governance transparency should also be stressed outside the national corporate governance code. In its current edition, the international good-practice framework COBIT 5 already refers to the importance of ensuring stakeholder transparency in the context of IT governance. However, this discussion remains rather high-level and abstract. Practitioners would certainly benefit from more specific guidelines regarding IT governance transparency for different stakeholder groups as part of the COBIT framework.

\section{Limitations and opportunities for future research}

In this final section, we discuss the limitations of our research and identify related opportunities for future work. First, this research only deals with disclosed information. There could very well be discrepancies between what is reported and what is implemented regarding IT governance. For instance, an organization may have a dedicated CIO function, but it is possible that this is not explicitly mentioned in their annual report. It would therefore be very interesting to link this study with IT governance maturity to detect discrepancies between the IT governance implementation in organizations and their disclosure. Second, this study deals with a relatively small sample size $(\mathrm{N}=20)$. This was motivated by a strong focus on the internal validity of the research and an in-depth discussion of the issues, but it stands without question that a large-sample study would be interesting. If the sample size is large enough, statistically significant differences in the proportions could be tested for using z-tests, which in turn would increase the reliability of the results. Another opportunity for future research is data triangulation. This study only used annual reports as a data source. This was motivated by the fact that annual reports seem to be the preferred medium for IT governance-related disclosure. Nevertheless, data triangulation using additional data sources (e.g. press releases, company website, etc.) would enable a richer understanding of a firm's IT governance disclosure. Finally, this research only deals with the quantity of publicly available IT (governance)-related information. It would be interesting to also investigate the quality of such information, as is sometimes analyzed in the area of corporate governance disclosure.

\section{Acknowledgment}

The authors would like to acknowledge the Belgian Agency for Innovation by Science and Technology, as one of the authors (Tim Huygh) is being funded by their $\mathrm{PhD}$ grant for strategic basic research at the time of conducting this research.

\section{References}

[1] P. Weill and J. W. Ross, IT Governance: How Top Performers Manage IT Decision Rights for Superior Results. Harvard Business Press, 2004.

[2] R. Huang, R. W. Zmud, and R. L. Price, "Influencing the effectiveness of IT governance practices through steering committees and communication policies," Eur. J. Inf. Syst., vol. 19, no. 3, pp. 288-302, Mar. 2010. 
[3] S. De Haes and W. Van Grembergen, “An Exploratory Study into IT Governance Implementations and its Impact on Business/IT Alignment," Inf. Syst. Manag., vol. 26, no. 2, pp. 123-137, Apr. 2009.

[4] A. Prasad, P. Green, and J. Heales, "On IT governance structures and their effectiveness in collaborative organizational structures," Int. J. Account. Inf. Syst., vol. 13, no. 3, pp. 199-220, Sep. 2012.

[5] D. Augustine, "Good Practice in Corporate Governance: Transparency, Trust, and Performance in the Microfinance Industry," Bus. Soc., vol. 51, no. 4, pp. 659-676, Jul. 2012.

[6] C. C. Millar, T. I. Eldomiaty, C. J. Choi, and B. Hilton, "Corporate Governance and Institutional Transparency in Emerging Markets," J. Bus. Ethics, vol. 59, no. 1-2, pp. 163-174, Jun. 2005.

[7] R. D. Morris, T. Pham, and S. J. Gray, "The Value Relevance of Transparency and Corporate Governance in Malaysia Before and After the Asian Financial Crisis," Abacus, vol. 47, no. 2, pp. 205-233, Jun. 2011.

[8] A. Joshi, L. Bollen, and H. Hassink, "An Empirical Assessment of IT Governance Transparency: Evidence from Commercial Banking," Inf. Syst. Manag., Feb. 2013.

[9] S. De Haes and W. Van Grembergen, Enterprise governance of information technology, second edition. Springer, 2015.

[10] R. Nolan and F. McFarlan, "Information technology and the board of directors," Harv. Bus. Rev., vol. 83, no. 10, p. 96-+, Oct. 2005.

[11] T. Heart, H. Maoz, and N. Pliskin, "From Governance to Adaptability: The Mediating Effect of IT Executives' Managerial Capabilities," Inf. Syst. Manag., vol. 27, no. 1, pp. 42-60, Jan. 2010.

[12] M. Mähring, "The Role of the Board of Directors in IT Governance: A Review and Agenda for Research," AMCIS 2006 Proceedings. 2006.

[13] W. Raghupathi, "Corporate Governance of IT: A Framework For Development," Commun. ACM, vol. 50, no. 8, pp. 94-99, Aug. 2007.

[14] R. R. Peterson, "Crafting Information Technology Governance," Inf. Syst. Manag., vol. 21, no. 4, pp. 7-22, Sep. 2004.

[15] P. M. Healy and K. G. Palepu, "Information asymmetry, corporate disclosure, and the capital markets: A review of the empirical disclosure literature," J. Account. Econ., vol. 31, no. 1-3, pp. 405-440, Sep. 2001.
[16] ISACA, "COBIT 5: Enabling Processes," 2012.

[17] IT Governance Institute (ITGI), "Board Briefing on IT Governance, 2nd Edition," 2003.

[18] R. Libby, R. Bloomfield, and M. W. Nelson, "Experimental research in financial accounting," Accounting, Organ. Soc., vol. 27, no. 8, pp. 775-810, Nov. 2002.

[19] A. S. Sohal and P. Fitzpatrick, "IT governance and management in large Australian organisations," Int. J. Prod. Econ., vol. 75, no. 1-2, pp. 97-112, Jan. 2002.

[20] R. Butler and M. J. Butler, "Beyond King III : assigning accountability for IT governance in South African enterprises," South African J. Bus. Manag., vol. 41, no. 3, pp. 33-45, 2010.

[21] M. Schreier, Qualitative content analysis in practice. Sage, 2012.

[22] O. Turel and C. Bart, "Board-level IT governance and organizational performance," Eur. J. Inf. Syst., vol. 23, no. 2, pp. 223-239, Feb. 2014.

[23] C. Bart and O. Turel, "IT and the Board of Directors: An Empirical Investigation into the 'Governance Questions' Canadian Board Members Ask about IT," Sep. 2010.

[24] D. S. Preston and E. Karahanna, "Antecedents of IS Strategic Alignment: A Nomological Network," Inf. Syst. Res., vol. 20, no. 2, pp. 159-179, Jun. 2009.

[25] D. Chatterjee, V. Richardson, and R. Zmud, "Examining the Shareholder Wealth Effects of Announcements of Newly Created CIO Positions," Management Information Systems Quarterly, vol. 25, no. 1. 2001.

[26] B. Dehning, V. J. Richardson, and R. W. Zmud, "The value relevance of announcements of transformational information technology investments," MIS Q., vol. 27, no. 4, pp. 637656, Dec. 2003.

[27] K. S. Im, K. E. Dow, and V. Grover, "Research Report: A Reexamination of IT Investment and the Market Value of the Firm-An Event Study Methodology," Inf. Syst. Res., vol. 12, no. 1, pp. 103-117, Mar. 2001.

[28] K. Campbell, L. A. Gordon, M. P. Loeb, and L. Zhou, "The economic cost of publicly announced information security breaches: empirical evidence from the stock market," $J$. Comput. Secur., vol. 11, no. 3, pp. 431-448, Apr. 2003.

[29] L. Gordon, M. Loeb, and T. Sohail, "Market Value of Voluntary Disclosures Concerning Information Security," Management 
Information Systems Quarterly, vol. 34, no. 3. pp. $567-594,2010$.

[30] IT Governance Institute (ITGI), "Global Status Report on the Governance of Enterprise IT (GEIT)," 2011.
[31] E. Oz, "Information technology productivity: in search of a definite observation," Inf. Manag., vol. 42, no. 6, pp. 789-798, Sep. 2005. 